\title{
SNAP25 Gene
}

National Cancer Institute

\section{Source}

National Cancer Institute. SNAP25 Gene. NCI Thesaurus. Code C127882.

This gene plays a role in neurotransmitter release and plasma membrane recycling. 